\title{
EARLY INTERVENTION MODEL TO ENHANCE COMMUNICATION SKILLS SOCIAL INTERACTION AND CHILDREN WITH AUTISM SPECTRUM DISORDERS
}

\author{
Oom Sitti Homdijah ${ }^{\mathrm{a}}$, Tjutju Soendari ${ }^{\mathrm{b}}$
}

Corresponding e-mail: Oomshomdijah51@gmail.com

\begin{abstract}
The research was motivated because of every year the population of children with Autism Spectrum Disorders (ASD) continues to increase. An autism spectrum disorder characterized by three impairments (triad of impairments) are impairment of social communication, impairment of social interaction and behavior. The impact of stress on the family as for their children with GSA disorder can occur either internally or externally. Goal of research is a model of early intervention to enhance social interaction and communication skills of children with GSA. The method used is the Research and Development, with a primary emphasis on the qualitative approach, descriptive analysis, by interview and observation. The results showed that there are parents who initially could not accept, and even today is still not able to accept the children unconditionally and their stress because of confusion how to communicate with their children, but if there is a problem that must be faced by families support each other, think together solution. Early intervention is not well developed in the family, parents prefer intervention by the therapist rather than doing it yourself.
\end{abstract}

Keywords: $\quad$ keyword, keyword, keyword

\section{INTRODUCTION}

Research was motivated because of every year the population of children with Autism Spectrum Disorders (ASD) continues to increase. Prior to 2006, the prevalence of children with ASD still around 1: 500. Data UNESCO in 2011 recorded approximately 35 million people with autism in the world. In Indonesia, the prevalence of children with GSA is 1: 165 (Kresno Mulyadi, 2010). Other data showed that the WHO (World Health Organization) states that in the last 10 years this GSA in Indonesia is rising rapidly, which previously 1: 1000, is now 8: 1000, or about 1: 125 (Kompas, 17 November 2011).

Autism spectrum disorder is primarily concerned with three main impairments are impairment of social communication, impairment of social interaction and repetitive behavior. Over the past decades, a number of related features also associated with autism spectrum disorders have received increased understanding and attention. This include: the sensitivity of sensory, cognitive (type of visual learning; the problem of attention and information processing), are less able to empathize (theory of mind, emotional problems, and characteristic is covert (Dodd, 2005: 3).

The existence of children with ASD influence on the family. Having a child with the disorder ASD is own pressure to the parents. Cathy Pratt (2008), a Director of the Indiana Resource Centre for Autism (IRCA), states that when children diagnosed with autism, families often face financial and social challenges. Stress continues to be substantial when the whole family become victims and family relations to be disrupted, even this stress contributes to the high divorce rate among parents. Family stress happens because they mostly do not understand about kids with ASD, so that they cannot raise children properly.

The impact of stress on the family as for their children with the disorder can happen to a family ASD both internally and externally. Kathy Labos (2005) states that the internal stress can be divided into stress in the elderly; stress on siblings; the stress of marriage; due to financial stress. Stress on parents is like a feeling of guilt and fear. Guilty has a high contribution that cause stress on families, especially in the elderly, other than guilt, fear is also a cause of stress in older people and has contributed high-stress after guilty. Stress this if not addressed will cause an 
imbalance in the family, no harmony, and will make families vulnerable, uncomfortable and unsafe.

All this time intervention in children with ASD is mostly conducted by therapist who are knowledgeable about the handling of children with impaired ASD, and focus only on the child, not the family. The paradigm of education of children with special needs have changes from the medical approach to a social approach. Social approach, more emphasis on respect for the individual because every individual is different, both in the ability to learn and also barriers to learning, characteristic in social approach is considered as personal identity, so the educational service for children with special need is not on the individual but on environment modification to help children to achieve optimally development. This applies not only in formal education but also in informal education or education in families.

Based on the above description shows that the family has a very important role in the lives of early childhood and family-based early intervention can make an impact to improve communication skills and social interactions of children with Autism Spectrum Disorders optimally.

\section{RESEARCH METHODS}

The study design used in this research is the Research and Development. Brog and Gall (1979: 624) argues "Educational Research and Development is a process used to develop and validate educational product", and for the effectiveness of the model using experimental method with single-subject research design (single subject research design). The main emphasis of this research on a qualitative approach to interviewing techniques.

The research step is:

a. At this preliminary stage researchers used a qualitative approach and implementation in the preliminary stage is divided into three activities, the first is the study of the theory of child development. Conceptualization basis of this research is explored through the study of Child Development (Laura Berk, 2003), Life-Span Development (John Santrock, 2011), Ecological Human Development (Bronfenbrenner, 1979), Bronfenbrenner's Ecological Systems Theory (Dede Paquette dan John Ryan, 2001); The Bronfenbrenner Ecological Systems Theory of Human Development (Ula Harkonen,2007); Bronfenbrenner Ecological Theory (Yukti Ahuja). Early Childhood Intervention Shaping the Future for Children with Special Need and Their Family Volume1, Volume 2 dan Volume
3, (2011), Family System Theory, Family Functioning Scale, The Development of Famili Quality of Life Concepts and Measures; zone of proximal development (Kozulin,: 2003); Autistic Spectrum Disorders (Dianne Zager, 2005; Susan Dodd, 2005). The study results of theory will be the basis for building a model of family-based interventions in improving communication and social interaction skills in children with autism spectrum disorders.

b. Empirical studies, researchers conducted interviews and observations of the families who have children with ASD. Data from empirical studies is first obtained through interviews with parents who have children with ASD early age associated with the quality of family life (Family Quality of Life) is expressed by Isaacs et al (2007) using the nine domains of family of life are: health of family; welfare, including the financial condition (financial well-being); family relationships; support from others; support from disability services; influence of value; careers and preparing for careers; the use of leisure time; and community involvement. Goal subsequent empirical studies conducted in children with ASD. Aimed the empirical studies in children with ASD is: (1) the development of communication skills and social interaction of children with ASD: language skills in verbal, nonverbal language and gestures.; (2) communication skills and social interaction children with ASD in the family; (3) the children with ASD barriers to develop communication skills and interaction.; (4) the learning needs of children with ASD to develop communication skills and social interaction

c. Model Development, activities performed are: (1) Introduction (gather information), (2) Planning, (3) Development of Model (develop an early form of the product) (4) Initial model revision (revised main product ), (5) test main field (6) the operational processes the product, (7) the operational field testing), (8) Revision of the final product, (9) dissemination and implementation model (dissemination and implementation) (Borg and Gall, 2003: 127).

d. To examine the effectiveness of the model used design A-B-A, where $\mathrm{A}$ is the first baseline, intervention and $\mathrm{B}$ is $\mathrm{A}$ second is the baseline to two. To view the baseline (A) to the two must be no lag time is longer than intervention which at both baseline that aims to see the results of the intervention constancy. 


\section{RESEARCH RESULTS}

The uniform appearance will assist the reader to read paper of the proceedings. It is therefore suggested to authors to use the example of this file to construct their papers. This particular example uses an American letter format with $25 \mathrm{~mm}$ margins left, right, top and bottom.

The research results were obtained profiles of parents and children as a basis for making an early intervention model to improve social interaction and communication skills of children with autism spectrum disorders.

\subsection{Parents Profile}

\subsubsection{Parent 1}

\section{1) Competence}

Ls and husband had a desire to better understand their children by seeking reference about the barriers that held her and also how to handle. Have the hope that his son will be able to develop optimally and can live adaptive to the environment. Can be independent. Ls and her husband are very concerned about their children, especially for the health and future. They have health funds (health insurance), they try to take their children to places of therapy, the family includes a harmonious family, they are open to another. In his spare time they took his son out of the house for a walk, or eat in restaurants.

2) Barriers

Barriers meant everything into the difficulties experienced by parents in dealing with their children. There were visible from the interviews that parents (mother and father) cannot accept fully that their children including children with autistic disorder. Mom does not have a desire to communicate about his condition to his family, still feel uncomfortable when some people were saying about her shortcomings, so that his motion was a little limited. Mother and father that their child is still trying to be like children in general. When a speech therapy say that their children included in children with nonverbal GSA, the mother did not receive.

3) Requirement needed

From the results of the assessment can be seen that the mother requires an understanding of children with autism spectrum disorders and accept the conditions of the child unconditionally, and has the courage to admit his condition so as to have the desire to intervene directly to his son so that the child can develop optimally.

\subsubsection{Parent 2}

1) Competences

Mom was able to accept her condition unconditionally, she received her according to her condition, she was not much demand in children, which is important child development can develop optimally. Advice from experts note, he was among those who shabar in encountering her condition is sometimes screaming (tantrums).

2) Barriers

Acceptance of the child is still not fully, still looking for a good school, and still treating the expert indirectly, by himself.

3) Requirement needed

Need a lot of practice to intervene in the child according to his learning needs.

\subsubsection{Parent 3}

1) Competence

MH can understand her well, in some ways could handle the children. Always want to give the best for their children in the optimization of its development. Even a single mother but tetep keep the family together with maintain a relationship with her ex-husband.

2) Barriers

MH does not follow association or participate in organizations associated with children with special needs.

3) Requirement needed

Needs a lot of activities with organizations related to children with special needs in order to further develop her insight.

\subsubsection{Parent 4}

\section{1) Competence}

Families UI is a family that has a clear function, which is where the father is a priest in the family. They educate children demga not differentiate from one another even though inclusive including children with GSA, but the child is treated fairly, not privileged or treated like children with disabilities khusus.Orang parents have an understanding of the child's condition, and enough discipline to their children. They impose discipline and rules to all members of the family.

2) Barriers

UI and families still feel confused to membelajarkan her to communicate with the environmental and social berinteraks families and neighborhoods, is also confused for so their children do not impulsive (enter people's houses at random).

3) Requirement needed 
Need the knowledge of how to develop communication with the child, especially when the child has the desire of parents can understand, and teaching of social rules.

\subsubsection{Parent 5}

1) Competence

Families can receive and understand her well that his son should be a diet, then their parents will arrange their children's diet with rationalization to optimize child development and reduce behavior disorders.

2) Barriers

For some reason $\mathrm{MG}$ still cannot let their children play and mingle with another children.

3) Requirement needed

Should strive to let their children get along with peers in the community with supervision.

\section{DISCUSSION}

The results showed that there are parents who are less able to accept children with ASD conditions, the psychological stress experienced by parents lasted for almost a year, both parents are inconsistent and conflict, especially when they know their child's condition. Cathy Pratt (2008), a Director of the Indiana Resource Centre for Autism (IRCA), states that when children diagnosed with autism, families often face financial and social challenges. Stress continues to be substantial when the whole family become victims and family relations to be disrupted, even this stress contributes to the high divorce rate among parents. Family stress happens because they mostly do not understand about children with impaired ASD, so that they can not raise children properly.

The results of interview showed that the family has a clear function, where the father as the head of the family is trying to protect family members, meet the needs of the family. The parents were divorced father still has a role when there are problems in the family. They are still in a relationship between a father and mother, sit together to find solutions to problems associated with their children. Berns (2004) states that the family has five basic functions: (1) The function of reproduction, the family has a duty to maintain and develop the existing population in the community for the sustainability of future generations; (2) The function of socialization, the family is the transmitter of values, knowledge, attitudes, skills from the previous generation to the next; (3) Assignment of social roles, the family is a means to provide the identity of the other family members, such as race, ethnicity, socio-economic, religious and gender roles; (4) supporting economy, families have the functionality to meet the food and clothing the other family members; (5) Emotional support / maintenance, family interaction and communication experience, the first for children, in which the interaction and communication that is based on love and compassion that are deep, caring, nurturing thus providing a sense of security to other family members.

Friedman (1998), revealed that the family function covers several aspects: (1) The function of affective is the function of internal affective family who will be the strength of the family to support each other, appreciate each other in a frame of love, mercy and compassion; (2) The function of socialization which is a function associated with the development of social interaction in the family. The family is the first place for children to interact and socialize; (3) The function of reproduction is the function of the family to continue the descent from one generation to the next so that the community maintained; (4) The function of health care is that the family has a function to keep the family members of health problems, caring for family members when having health problems, maintain the health of each family member's health both physically and emotionally social.

\section{REFERENCES}

[1] Sujana M.G., Anand S. (2011). Fluoride removal studies from contaminated ground water by using bauxite. Desalination, 267, 222227.

[2] Ahuja, Y, (....), Bronfenbrenner Ecological Teory, tersedia online: www.mymontessoriacademy.com/.../websitebr onfenbrennerecologicaltheory

[3] American Psychiatric Association (2000), Diagnostik and Statistical Manual of Mental Disorders, Washington DC.: American Psychiatric Association Publisher.

[4] Brendtro, L. K., (2006), The Vision of Urie Bronfenbrenner: Adults Who Are Crazy About Kids: Reclaiming Children and Youth; Fall 2006; 15, 3; ProQuest pg. 162

[5] Bronfenbrenner, Urie (1979) The Ecology of Human Development, United States of America: Harvard University Press.

[6] Dodd, Susan, (2005), Understanding Autism, Australia: Elsevier

[7] Christensen-Sandfort, Robyn J. and Whinnery Stacie B. (2011), Impact of Milieu Teaching on Communication Skills of Young Children With Autism Spectrum Disorder, tersedia online: 
http://tec.sagepub.com/content/early/2011/04/1 3/0271121411404930

[8] Feist, J and Feist, G.J., (2006), Theories of Personality, New York: McGraw Hill.

[9] Greenspan, Stanley I., (1997), (1998), The Child with Special Needs, Massachusetts: Perseus Book.

[10]Guhn, M., and Goelman, H. (2011), Bioecological Theory, Early Child Development and the Validation of the Population-Level Early Development Instrument: Soc Indic Res (2011) 103:193-217

[11] Guiffrida, D and Douthit, K, Z, (2007), Book Review of Crisis and Trauma: DevelopmentalEcological Intervention:Journal of Counseling and Development : JCD; Summer 2007; 85, 3; ProQuestpg. 378

[12] Hancock, TB. and Kaiser, P. (2006), Enhanced Milieu Teaching. In R. McCauley \&M. Fey (Eds.) Treatment of Language Disorders in Children. Baltimore: Paul Brookes

[13]Hoghdon, Linda A., (1999), Visual Strategis For Improving Communication Practical Support for School and Home, Michigan, USA: Quick Roberts Publishing.

[14]Hogan, Kerry, (2003), Nonverbal Thinking, Communication, Imitation, and Play Skills From a Developmental Perspective, Tersedia: file://F: $\backslash \mathrm{BP} \backslash$ Division TEACCH Communication Approaches_files\develop.htm (22 September 2003)

[15] Howlin, Patricia, \& Hadwin, Julie, (1999), Teaching Children with Autism to Mind-Read, A Practical Guide for Teacher and Parents, New York: John Wiley \& Sons.

[16]Kaiser, AP and Trent, JA (2007), Communication Intervention for Young Children with Disabilities Naturalistic Approaches to Promoting Development, In Odom, S.L. et. al. (2007), Handbook of Developmental Disabilities, New York: The Guilford Press

[17] Morgan, D.L. and Morgan, R.K, (2009), Single - Case Research Methods for the Behavioral and Health Sciences, London: Sage

[18]Murray, Dona S. et al. (2008), The Relationship Between Joint Attention and Language in Children with Austim Spectrum Disorders, Focus on Autism and Other Developmental Disabilities. Volume 23 Number 1 March, 20085 -14

[19] Myer, R.A, \& Moore, H.B, (2006), Crisis in context theory: an ecological model: Journal of Counseling and Development, Spring, 2006; 84,2; ProQuest pg. 139

[20]Naber, et al. (2007), Joint Attention and Attachment in Toddlers with Autism, tersedia online:www.springerlink.com/index/5402u033 23173578.pdfhttp://www.pediatricsdigest.mobi /content/108/5/1155.full.pdf+htmlhttp://autism aus.com.au/uploads/pdfs/PrevalenceReport.pdf

[21] Onwuegbuzie, A.J, Collins, K.M.T and Frels, R.K, Foreword: Using Bronfenbrenner's ecological systems theory to frame quantitative, qualitative, and mixed research: International Journal of Multiple Research Approaches(2013) 7(1): 2-8.

[22] P. S. Samuel, F. Rillotta \& I. Brown, 2012, The development of family quality of life concepts and measures, Journal of Intellectual Disability Research, volume 56 part 1 pp 1-16 january 2012

[23]Peterson, Pete., Carta, Judith J. and Greenwood, Charles, (2005) Teaching Enhanced Milieu Language Teaching Skills to Parents in Multiple Risk, Journal of Early Intervention, Vol. 27, No. 2, 94 - 109, tersedia online: http://jei.sagepub.com/content/27/2/94

[24] Peeters, Theo, (1998), Autism From Theoritical Understanding to Educational Intervention, London: Whurr Publisher Ltd.

[25] Peirson, L.J, Boydell, K.M, Ferguson, H.B., Ferris, L.E, (2011),An Ecological Process Model of Systems Change: Am J Community Psychol (2011) 47:307-321

[26] Quill, K, Ann, (2000), Do-Wacth-Listen-Say, Baltimore: Paul H Brooke.

[27] Quill, K, Ann . (1995), Teaching Children with Autism,New York USA:Delmar Publisher Inc.TM

[28]Rakhmat, Jalaluddin, (2003), Psikologi Komunikasi Ed. Revisi, Bandung: Remaja Rosdakarya.

[29] Rechly, A.L \& Christenson, S.L.,Moving From "Context Matters" to EngagedPartnerships With Families, Journal of Educational and Psychological Consultation, 22:62-78, 2012

[30] Shogren, K.A, (2013), A Social-Ecological Analysis of the Self-Determination Literature: Intelectual and Developmental Disabilities 2013, Vol. 51, No. 6, 496-511.

[31] Swick, K.J, and Williams, R.D., (2006), An Analysis of Bronfenbrenner's Bio-Ecological Perspectivefor Early Childhood Educators: Implications for Workingwith Families Experiencing Stress: Early Childhood Education Journal, Vol. 33, No. 5, April 2006

[32] Syamsuddin, Abin, (2005), Psikologi Kependidikan Perangkat Sistem Pengajaran Modul, Bandung: Remaja Rosdakarya

[33] Sunanto, J. (2005). Pengantar Penelitian dengan Subjek Tunggal. Jepang: University of Tsukuba 
[34] Threvarthen, Colwyn, (1999), Children With Autism, Second Edition, Philadelphia: Jessica Kingsley Publisher.

[35] Waterhouse, Stella, (2000), A Positive Approach to Autism, London and Philadelphia: Jessica Kingsley Publisher

[36] Wertsch, J.V., (2005),Making human beings human: Bioecological perspectives on human development: The British Journal of Developmental Psychology; Mar 2005; 23, ProQuest pg. 143.

[37] Wetherby, Amy M. dan Prizant, Barry M. (2001), Autism Spectrum Disorder A Transactional Developmental Perspective, Baltimore, Maryland: Paul H. Brookers Publishing
[38] Wing, Lorna, (1974), Autistik Children A Guide for Parents and Professionals, New Jersey: The Chitadel Press

[39] Volkmar, F.D, Paul, R, Klin,A, Cohen, D, (2005), Handbook of Pervasive Devlopmental Disorders Volume 1, third edition, New Jwesey: John Willey \& Sons, Inc

[40] Yuniar, Sasanti, (2003), Masalah Perilaku pada Gangguan Spektrum Autime (GSA) (makalah) Jakarta: Konferensi Nasional Autisme-I

[41]Zager, D, (2005), Autism Spectrum Disorders Identification, Education and Treatment, third edition, London: Lawrence Erlbaum Associates Publishers 